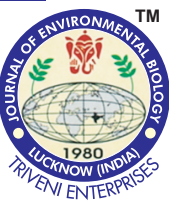

\title{
Histopathological and cholinesterase changes in the gills of Clarias gariepinus as a result of cadmium exposure
}

\begin{tabular}{lll}
\hline Paper received: 20.02.2017 $\quad$ Revised received: 10.11.2017 Re-revised received: $02.10 .2018 \quad$ Accepted: 03.12 .2018 \\
\hline
\end{tabular}

\section{Authors Info}

A.A.F.M. Pariza', S.A. Ahmad*1, N.I. Fadzil', A.A. Basirun', S.A.W. Sha'arani', N.A.M. Asri', M.K. Sabullah', A. Khalid ${ }^{3}$ and M.Y. Shukor ${ }^{1}$

'Department of Biochemistry, Faculty of Biotechnology and Biomolecular Sciences, Universiti Putra Malaysia, UPM, 43400 Serdang, Selangor, Malaysia ${ }^{2}$ Faculty of Science and Natural Resources, Universiti Malaysia Sabah, Jalan UMS, 88400, Kota Kinabalu, Sabah, Malaysia

${ }^{3}$ Faculty of Health Sciences, Universiti Kebangsaan Malaysia, Jalan Raja Muda Abdul Aziz, 50300 Kuala Lumpur, Malaysia

*Corresponding Author Email : aqlima@upm.edu.my

\section{Edited by \\ Dr. R.B. Raizada}

Reviewed by

Dr. Kamal Sharma

Dr. K.M. Rajesh

\section{Abstract}

Aim : The cholinesterase (ChE) based inhibition and histopathological studies from fish were investigated and represented in this study to develop as one of the great potential biomarkers for heavy metals monitoring.

Methodology : In this study, the histopathological study of gills were observed a under microscope. The capability of ChE extracted from the gills of Clarias gariepinus was assessed for declining $\mathrm{Cd}$. ChE was purified through affinity chromatography and continued with the optimisation and inhibition study $\left(\mathrm{IC}_{50}\right)$ of cholinesterase.

Results : Histopathological study of gills was carried out and several changes such as aneurysm, necrosis and lamella fusion were noted. Purification fold obtained from purified enzyme was 1.15 with $30 \%$ a yield specific activity 20.726 . The optimum temperature for purified AChE was $35^{\circ} \mathrm{C}$ along with acetylthiocholine iodide (ATC) as a preferable substrate that had the highest $V_{\max }$ value of $0.5452 \mathrm{U} \mathrm{mg}^{-1}$ and the lowest $\mathrm{K}_{\mathrm{m}}$ value of $0.0311 \mathrm{mM}$. The optimum $\mathrm{pH}$ was observed to be 10 of Tris- $\mathrm{HCl}$ as a medium. Meanwhile, the $\mathrm{IC}_{50}$ of cadmium was $6.808 \mathrm{mgl}^{-1}$ with $R^{2}$ value of 0.9532

Interpretation: The result of the study
Cholinesterase activity and histopathological changes as a biomarker
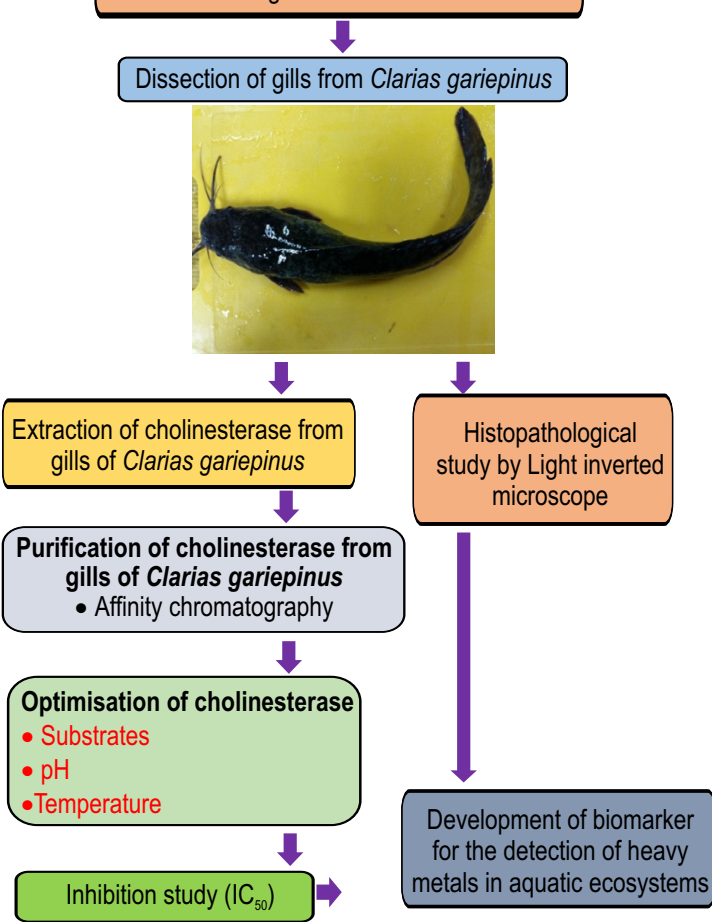
can be used as a tool for further developing a biomarker for the detection of heavy metals in aquatic ecosystems. In addition, the baseline data provided can also be used for designing a kit, which would give rapid and accurate result.

Key words: Acetylcholinesterase activity, Biomarkers, Cadmium, Clarias gariepinus, Histopathological study

How to cite : Pariza, A.A.F.M., S.A. Ahmad, N.I. Fadzil, A.A. Basirun, S.A.W. Sha'arani, N.A.M. Asri, M.K. Sabullah, A. Khalid and M.Y. Shukor: Histopathological and cholinesterase changes in the gills of Clarias gariepinus as a result of cadmium exposure. J. Environ. Biol., 40,683-690 (2019). 


\section{Introduction}

In recent years, pollution of aquatic environment by heavy metals has become a global problem. Heavy metals enter the aquatic environment either by natural or anthropogenic sources. The natural sources include aerial fallout, industrial/urban effluents, as well as surface run off from the anthropogenic sources. The food chain is endangered as marine life is the main protein and top consumption source (Förstner et al., 2013). These problems exacerbate since metals get transported with sediments, persistent in the environment and can bio-accumulate in the food chain. Pollutants significantly affect the aquatic life and all trophic levels from primary producers to predators, ultimately humans. It may disturb the organisation of many freshwater fish species and other aquatic communities and hampering the normal balance of the ecosystem (Padrilah et al., 2017; Todd et al., 2010; Agtas et al., 2007).

Cadmium is regarded as one of the most toxic heavy metals as it causes sublethal and behavioural effects on the organisms at lower concentrations (Eisler, 1985). This has been proved in an experiment showing the ability of heavy metals to modify the chemical communication between individuals, which can result in info-disruption or false communication affecting ecological relationships within and between the species (Boyd, 2010). Moreover, cadmium is capable to accumulate in each organ, especially liver and kidney. The gills of fish are the primary target to toxicant before being transported to other organs, deposit in the muscles or are partially eliminated via excretion. Due to high accumulation of cadmium in muscles, the fish is considered unsafe for consumption. Continuous exposure to polluted water bodies such as river, ocean and sea which also contributes to the accumulation of heavy metals in fish (Sulaiman and Mei, 2013). A study conducted at Strait of Malacca demonstrated the presence of Cd in fish sample (Alina et al., 2012).

Fish are known to be an excellent biomarker due to its sensitivity towards toxicants (Hayat et al., 2016; Sabullah et al., 2015b; Tham et al., 2009). The gills of freshwater fish are the largest area of the body, direct in contact with the water (Kumar et al., 2015). Pollutants study revealed that gills are the first targets, which are involved in the breathing mechanism of fish (Hayat et al., 2015). Pollutants enter fish through gills and release their primary toxic effects on the brachial epithelium (Playle et al., 1992), therefore gills are selected parts to study the response of environmental stress and to indicate physical and chemical stresses (Au, 2004). Clarias gariepinus (catfish) is used as a biomarker for observing the effects of cadmium on the enzyme cholinesterase extracted from the gills. It is widely used in aquaculture and has become the subject of numerous studies in biochemistry (Hee and Kottelat, 2008).

Cholinesterase (ChE) inhibition has been used extensively as a biomarker for detecting heavy metal pollution (Ahmad et al., 2016c; Hayat et al., 2017). In this study, the potential of $\mathrm{ChE}$ from the gills of $\mathrm{C}$. gariepinus as an alternative biosensor for heavy metals was evaluated. Previous studies have reported that there can be more than one ChE present in the tissues of fish and these different forms may vary in their sensitivity to anticholinesterase agents (Monteiro et al., 2005; Padrilah et al., 2017). In the present study, attempts were made to elucidate the effect of cadmium on the histopathology and cholinesterase enzyme activity in gills of Clarias gariepinus. Moreover, the objective of this study was to determine the physical and behavioural changes of $C$. gariepinus inhibited by cadmium using in vivo method and to identify the minimal concentration and half maximal inhibitory concentration $\left(\mathrm{IC}_{50}\right.$ of cadmium that would produce significant changes in C. gariepinus.

\section{Materials and Methods}

Acclimatization and treatment: Irrespective of sex, healthy $C$ gariepinus weighing $100 \mathrm{~g}$ body weight and $20 \mathrm{~cm}$ long were procured from the Department of Fisheries, Semenyih, Selangor, Malaysia, were brought alive and acclimatized to laboratory conditions for five days in large glass aquariums supplemented with $40 \mathrm{I}$ of filtered dechlorinated tap water with full aeration. $C$. gariepinus were placed in glass aquariums containing filtered water and fed with commercial fish pellets (floating type) twice a day where the total pellet mass was $2 \%$ of the fish weight that contained $28-32 \%$ of protein level prior to the study. Fish were randomly distributed in eight groups of six fishes in each aquarium, with three replicates. Fish were treated with different concentrations of $\mathrm{Cd}\left(1,5,10,20,30,40\right.$ and $\left.50 \mathrm{mg} \mathrm{l}^{-1}\right)$. for $96 \mathrm{hrs}$ to generate $L_{50}$ data. These concentrations were selected to provide a baseline data on the concentration that trigger negative effects on the species. The water was filtered through the sponge layer filter to trap the remaining food waste and excrement, while hygiene and cleanliness of the water was maintained by renewing the filters daily. After the end of treatment, physical behaviour and morphological changes in the fish were observed.

Histopathological studies : Gills of treated and control fish were fixed in $10 \%$ neutral buffered formalin for $48 \mathrm{hrs}$ to inhibit decaying or autolysis of tissues so that the samples could be preserved for future study. Samples were then placed in the cassette and fixed again in $10 \%$ formalin. Samples were then subjected to tissue processing in which the cassette containing samples were immersed in alcohol with a series of ascending concentrations at a given time $(80 \%$ alcohol for $2 \mathrm{hrs}, 95 \%$ alcohol for $2 \mathrm{hrs}$ and $100 \%$ alcohol for $3 \mathrm{hrs}$ ), followed by chloroform and paraffin for 3 and $5 \mathrm{hrs}$ and $30 \mathrm{~min}$, respectively. The samples were then embedded into the wax and placed on a cold plate for 15 min until they became a block. After being embedded in wax, the samples were sectioned at $5 \mu \mathrm{M}$ thickness using a microtome and then stained using haematoxylin and eosin staining.

Extraction and purification: Gill samples were homogenised by adding $0.1 \mathrm{M}$ sodium phosphate buffer $(\mathrm{pH} 7)$, containing $1 \mathrm{mM}$ of phenylmethylsulfonyl fluoride (PMSF) (gill: buffer ratio is 1:4) using an Ultra-Turrax T25 homogeniser. The homogenate was centrifuged at $15,000 \times \mathrm{g}$ at $4^{\circ} \mathrm{C}$ for $20 \mathrm{~min}$. The supernatant 
collected after centrifugation was kept at $-25^{\circ} \mathrm{C}$ in a clean Falcon tube for further purification. The purification process was carried out by loading $15 \mathrm{ml}$ supernatant into the affinity column containing procainamide sepharyl 6B. $20 \mathrm{mM}$ of sodium phosphate buffer with $\mathrm{pH} 7.0$ (washing buffer) was added onto the column with a flow rate calibrated at $1.0 \mathrm{ml} \mathrm{min}^{-1}$ for washing. This stage is crucial as it eliminates the unbounded protein from the column to the matrix. The absorbed enzyme was then eluted using $20 \mathrm{Mm}$ sodium phosphate buffer containing $1 \mathrm{M} \mathrm{NaCl}$. Fractions of $1 \mathrm{ml}$ were collected starting from washing stage unti the end of elution stage. Each fraction was tested for enzyme activity and protein content following the method of Ellman et al. (1961) and Bradford (1976), respectively.

Estimation of acetylcholinesterase (AchE) activity and protein: AchE activity was estimated following the method of Ellman et al. (1961) with slight modification. A 96-well microplate was selected for examining the enzyme activity at $405 \mathrm{~nm}$ wavelength. Each microplate comprised $200 \mu$ sodium phosphate buffer (0.1 M, pH 7.0), $20 \mu$ l DTNB ( $0.1 \mathrm{mM})$ and 10 $\mu \mathrm{l} \mathrm{ChE}$, which were mixed and incubated for $15 \mathrm{~min}$. Later, $20 \mu \mathrm{l}$ of the substrates comprising $5.0 \mathrm{mM}$ of acetylthiocholine iodide (ATC), butyrylthiocholine iodide (BTC) and propionylthiocholine iodide (PTC) was added to the mixture and incubated for $10 \mathrm{~min}$ for the reaction to take place.

Optimal substrate specificity, $\mathrm{pH}$ and temperature: Purified ChE activity was tested with three synthetic substrate of $0.1 \mathrm{M}$ ATC, BTC and PTC of different concentrations $(0.1,0.5,1.0,2.0$, 5.0 and $10.0 \mathrm{mM}$ ) to determine the substrate specificity for $\mathrm{ChE}$ in sodium phosphate buffer (0.1 M, pH 7.0). Michaelis-Menten constant $\left(\mathrm{K}_{\mathrm{m}}\right)$ and maximal velocities $\left(\mathrm{V}_{\max }\right)$ of $\mathrm{ChE}$ activity were determined using GraphPad Prism 5 (Miller and Miller, 2000). The optimum $\mathrm{pH}$ was determined by incubating $\mathrm{ChE}$ with an overlapping buffer system that contained $0.1 \mathrm{M}$ acetate buffer $(\mathrm{pH}$ $3.0,4.0,5.0,5.5)$, sodium phosphate buffer ( $\mathrm{pH} 6.0,7.0,8.0)$ and Tris- $\mathrm{HCl}$ buffer $(\mathrm{pH} 7.0,8.0,9.0,10.0)$. To determine the optimal temperature for the enzyme, ChE sample was incubated for 15 $\min$ at $15,20,25,30,35,40$ to $50^{\circ} \mathrm{C}$.

Half maximal inhibitory concentration (Ic50): The effect of cadmium on $C$. gariepinus $\mathrm{ChE}$ were studied for a period of 96 hrs. The reaction mixture contained $150 \mu$ of Tris- $\mathrm{HCl}$ buffer $(0.1$ $\mathrm{M}, \mathrm{pH}$ 9), $50 \mu \mathrm{l}$ metal ion with a final concentration of $1 \mathrm{mg} \mathrm{l}^{-1}, 20 \mu \mathrm{l}$ DTNB ( $0.1 \mathrm{mM})$ and $10 \mu \mathrm{l} \mathrm{ChE}$. All mixtures were incubated for 15 $\min 20 \mu$ l of ATC ( $2.5 \mathrm{mM}$ ) was loaded into the mixtures followed by incubation with $10 \mathrm{~min}$ period. The absorbance was read at the end of incubation period at $405 \mathrm{~nm}$. The concentration of cadmium (1-50 mg I') inhibition profile was analysed and $\mathrm{IC}_{50}$ cadmium was obtained by GraphPad Prism software.

Statistical analysis: GraphPad Prism Software (Version 5) was used to analyse the data. In the characterisation study, values are represented as mean \pm SD. Student's t-test and one-way analysis of variance followed by post-hoc analysis by Tukey's test was used in evaluating statistical significance $(p<0.05)$ between groups.

\section{Results and Discussion}

During the study, the behaviour of fish was observed to be normal during the acclimatization period and at lower concentration of cadmium (1,5 and $10 \mathrm{ppm})$, the swimming rate and rate of excretion of fish were similar to control, considering no significant effect $(p<0.005)$ (Table 1$)$. The change in terms of decrement in excretion was observed from 20 to $50 \mathrm{ppm}$ of cadmium exposure. Visible change observed in most body parts of fish were damaged scales and lower swimming performance, which may be due to loss of energy or lethargy.

The fish were constantly found to remain at the surface, which may be due to difficult breathing as their gills were damaged. The gills may undergo loss of cellular architecture and cell degeneration (Chavan et al., 2014). Gills are the primary site of osmoregulation and respiration in aquatic vertebrates involved in the abundant secretion of mucus in a way to adapt to their own habitat (Athikesavan et al., 2006). The presence of heavy metals in the aquatic environment may increase mucus secretion which is one of the defence mechanism towards pathogen or commensals. Gills are the main target organ to be affected easily when an organism is exposed to dissolved heavy metals, affecting the fish in terms of behaviour, morphology and histology.

The fish exposed to 1, 5, 10, 20, 30, 40 and 50 ppm of cadmium showed several histopathological alterations (Fig. 1) such as aneurysm, lifting of respiratory epithelium, necrosis and fusion of secondary lamella. In a study conducted by Butchiran et al. (2012) similar changes as epithelial hyperplasia with lamellar fusion, epithelial hypertrophy, telangiectasia, oedema, general necrosis, increased mucous production and degeneration of primary and secondary gill lamellae were observed in the gills of Labeo rohita exposed to phenol. Aneurysm resultes due to the accumulation of blood in the secondary lamellae to protect the gill epithelia from infection and mechanical abrasions (Mabika et al., 2013) which might be used as a sensitive and reliable biomarker for acute toxicant exposure to metals, including cadmium and copper.

Epithelial lifting is one of the common acute inflammatory responses from the gills to pollutants by increasing the distance of pollutant and blood diffusion, impairing oxygen uptake. However, under these conditions, the fish increases its respiration rate by compensating for low (Mabika et al., 2013). Zeitoun and Mehana (2014) reported that the fusion of secondary lamella occurred in Tilapia nilotica exposed to environments that are heavily polluted with heavy metals as the fish were trying to limit the surface area of gills exposed to pollutant. That can be considered as a protective method. Necrosis occur when cells are highly damaged and can not perform common biochemical process, forcing it to die and rupture.

Acetylthiocholine indicates the highest amount of enzyme activity $(29.75 \mathrm{U})$ in crude extract that shows the most preferable substrate in gills. Acetylthiocholine as the most 
Table 1: Behavioural changes observed in C. gariepinus for 96 hrs during acclimatization and treatment

\begin{tabular}{|c|c|c|c|c|c|c|c|c|c|}
\hline \multirow[t]{2}{*}{ Observation } & \multicolumn{3}{|c|}{ Acclimatization } & \multicolumn{4}{|c|}{ Heavy metal treatment (ppm) } & \multirow[b]{2}{*}{40} & \multirow[b]{2}{*}{50} \\
\hline & For 6 Days & 0 & 1 & 5 & 10 & 20 & 30 & & \\
\hline \multicolumn{10}{|l|}{ 1) Fish behavior } \\
\hline Swimming performance & $* \star \star *$ & $* * * *$ & $* \star \star *$ & $* * *$ & *** & $* * *$ & ** & ** & ** \\
\hline $\begin{array}{l}\text { i. Swimming rate } \\
\text { ii. Swimming pattern }\end{array}$ & UD,B & UD,B & SASB,B & SASB,B & SASB,B & S & S & S & S \\
\hline (b) Fin movement & BW & BW & BW & BW & BW & BW & BW & BW & BW \\
\hline (c) Excretion & $* * *$ & $* * *$ & $* * *$ & $* * *$ & $* * *$ & ** & ** & ** & $* *$ \\
\hline $\begin{array}{l}\text { (d) Mucus like secretion } \\
\text { from gill }\end{array}$ & * & * & ** & ** & ** & $* *$ & $* * *$ & $* * *$ & $* * *$ \\
\hline (e) Scale condition & $* \star \star *$ & $* \star \star *$ & $* * *$ & $* * *$ & $* * *$ & $* * *$ & ** & $* *$ & ** \\
\hline 2. Food Intake & $* * * *$ & $* * * *$ & $* \star *$ & $* * *$ & $* * *$ & ** & ** & ** & $* *$ \\
\hline
\end{tabular}

Indicators: : very little, ${ }^{* *}$ : little, ${ }^{* * *}$ : moderate, ${ }^{* * * *}$ : high; UD $=$ up \& down, SASB $=$ some above, some below, $B=$ at the base of water, $S=$ at the surface of water, $\mathrm{BW}=$ backward
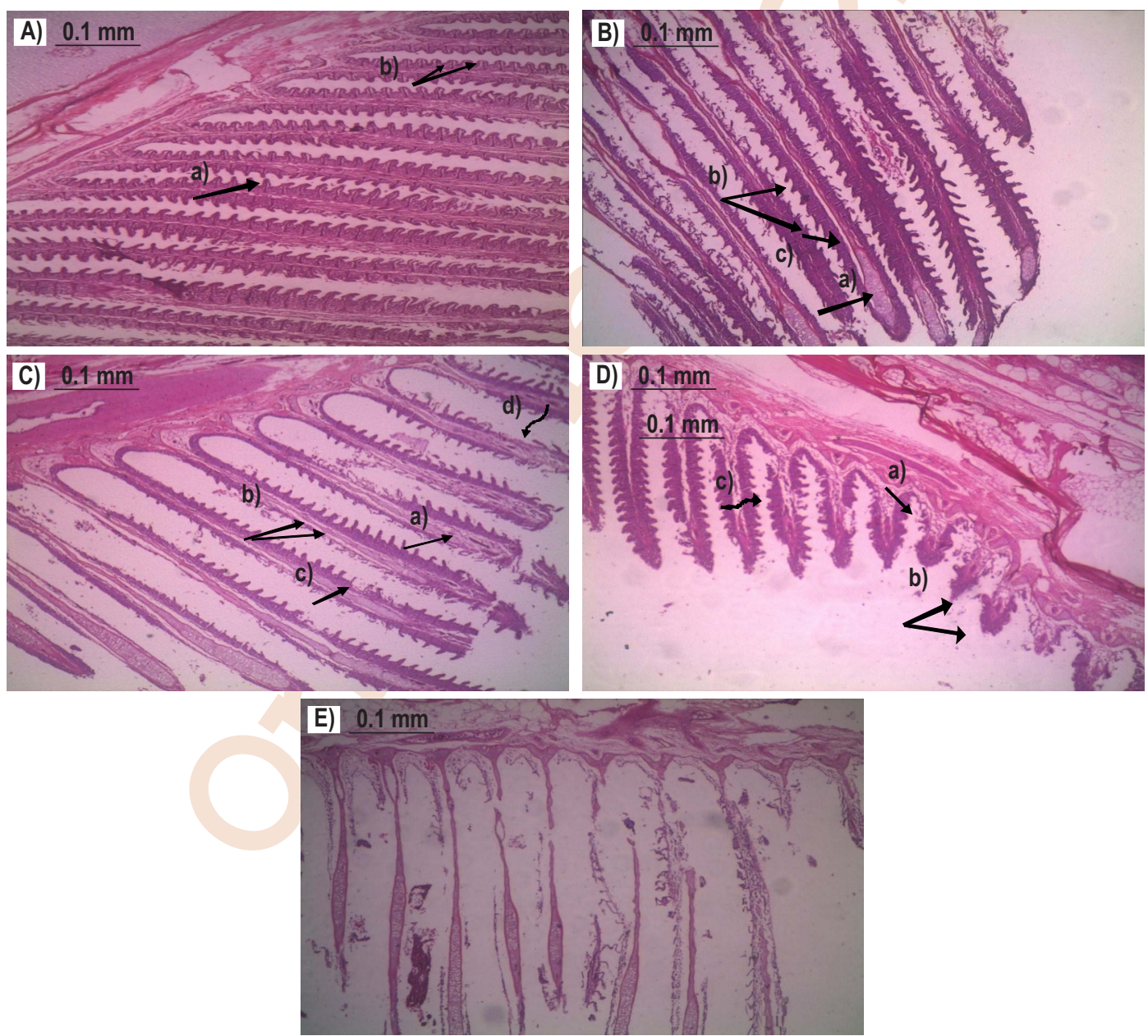

Fig. 1: (A) Normal gill tissue of C. gariepinus (4x magnification). a) Normal primary lamella, b) Normal secondary lamella. B) Gill tissue exposed to $5 \mathrm{mg} \mathrm{l}^{-1}$ of cadmium (4x magnification). a) Aneurysm effect on the primary lamella, b) Necrosis effect on the secondary lamella, c) Lifting of the respiratory epithelium. (C) Gill tissue exposed to $10 \mathrm{mg} \mathrm{l}^{-1}$ of cadmium (4x magnification). a) Aneurysm, b) Necrosis, c) Lifting of respiratory epithelium, d) Fusion of secondary lamella. (D) Gill tissue exposed to $30 \mathrm{mg} \mathrm{I}^{-1}$ of cadmium (4x magnification). a) Aneurysm, b) Necrosis, c) Fusion of lamella. E) Gill tissue exposed to $50 \mathrm{mg} \mathrm{I}^{-1}$ of cadmium (4x magnification). Completely degraded and damaged gills by the heavy metal. 


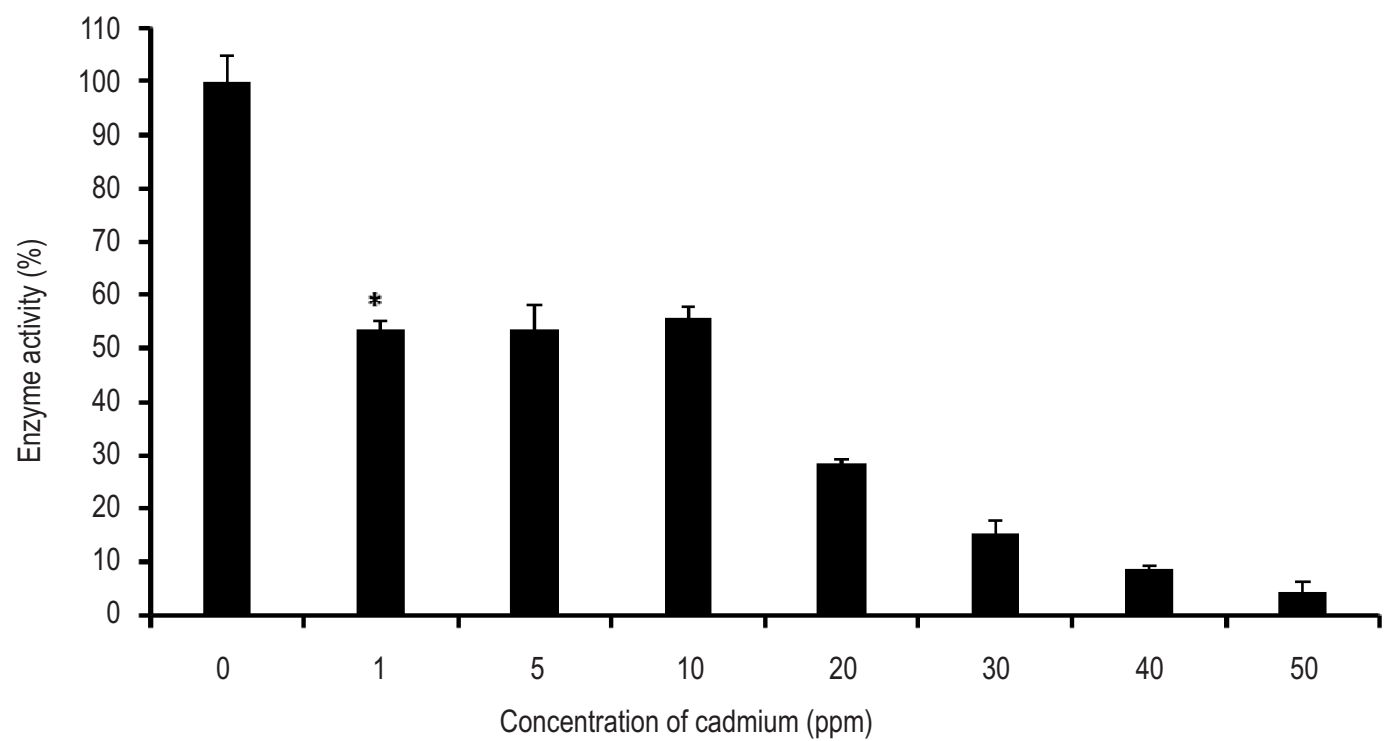

Fig. 2 : Inhibition of cholinesterase activity against varying cadmium concentrations. Error bar represent mean of three replicates \pm S.D.

abundant form of cholinesterase in gills has been reported earlier (Jebali et al., 2013; Mahboob et al., 2014). In the present study, the enzyme activity decreased by almost half at $1 \mathrm{ppm}$ and became stable at 5 ppm and $10 \mathrm{ppm}$ and drastically reduced at 20 ppm (Fig. 2) because the gills were damaged due to cadmium toxicity. Purification fold obtained from purified enzyme by affinity chromatography of Procainamide-Sephacryl 6B was 1.15 with $30 \%$ yield (Table 2 ), shows the ability of affinity chromatography to purify the protein. Mehrani (2004) and Li et al. (2008) demonstrated that Procainamide-Sepharose affinity chromatography is more suitable and effective way to purify cholinesterase and could eliminate a remarkable amount of proteins including albumin. The study conducted by Tham et al. (2009) on purification of Clarias batrachus cholinesterase showed that the partial purification of enzyme was successful with approximately 5 -fold purification and a good yield of nearly $50 \%$. Fig. 3 shows Michaelis-Menten kinetics curve formed using GraphPad Prism 5. The curve represents the result of hydrolysation by ChE for the substrates. Table 3 demonstrates different values for the enzyme activities when reacted with three types of substrates. Substrate acetylthiocholine recorded the highest $\mathrm{V}_{\max }$ value of 0.5452 and the lowest $\mathrm{K}_{\mathrm{m}}$ value of 0.0311 , suggesting the highest efficiency of 17.53 as compared to others. This result corr. Nigam et al. (2014). Hayat et al. (2016) recorded that $\mathrm{ChE}$ from $L$. calcarifer gills was capable of breaking down acetylthiocholine at a faster rate compared to other two synthetic substrates, i.e., butyrylthiocholine iodide and propionyl thiocholine iodide. Three types of buffer used for optimisation

Table 2 : Purification of ChE using ATC as substrate

\begin{tabular}{|c|c|c|c|c|c|c|c|c|}
\hline Sample & $\begin{array}{l}\text { Volume } \\
\text { (ml) }\end{array}$ & $\begin{array}{l}\text { Enzyme } \\
\text { activity (U) }\end{array}$ & $\begin{array}{l}\text { Total } \\
\text { activity (U) }\end{array}$ & $\begin{array}{l}\text { Protein content } \\
\left(\mathrm{mg} \mathrm{ml}^{-1}\right)\end{array}$ & $\begin{array}{l}\text { Total protein } \\
(\mathrm{mg})\end{array}$ & $\begin{array}{l}\text { Specific activity } \\
\left(\mathrm{U} \mathrm{mg}^{-1}\right)\end{array}$ & $\begin{array}{l}\text { Purification } \\
\text { fold }\end{array}$ & Yield (\%) \\
\hline Crude & 50 & 29.754 & 1487.745 & 2.551 & 127.563 & 16.561 & 1 & 100 \\
\hline Affinity & 15 & 26.335 & 395.028 & 0.787 & 20.726 & 20.726 & 1.151 & 30 \\
\hline
\end{tabular}

Table 3: Comparison of maximum velocity $\left(V_{\max }\right)$ and biomolecular constant $\left(K_{m}\right)$ for ATC, BTC and PTC of $C$. gariepinus ChE

\begin{tabular}{llll}
\hline Substrate & $\mathbf{V}_{\max }$ Specific activity & $\mathrm{K}_{\mathrm{m}}, \mathrm{mM}$ & $\begin{array}{l}\text { Catalytic efficiency } \\
\left(\mathbf{U} \mathrm{mg}^{-1} \text { protein }\right)\end{array}$ \\
\hline Acetylthiocholine iodide & 0.5452 & 0.0311 & 17.5305 \\
Butyrlthiocholine iodide & 0.2111 & 0.4169 & 0.5063 \\
Propionylthiocholine iodide & 0.5052 & 0.0450 & 11.2267 \\
\hline
\end{tabular}




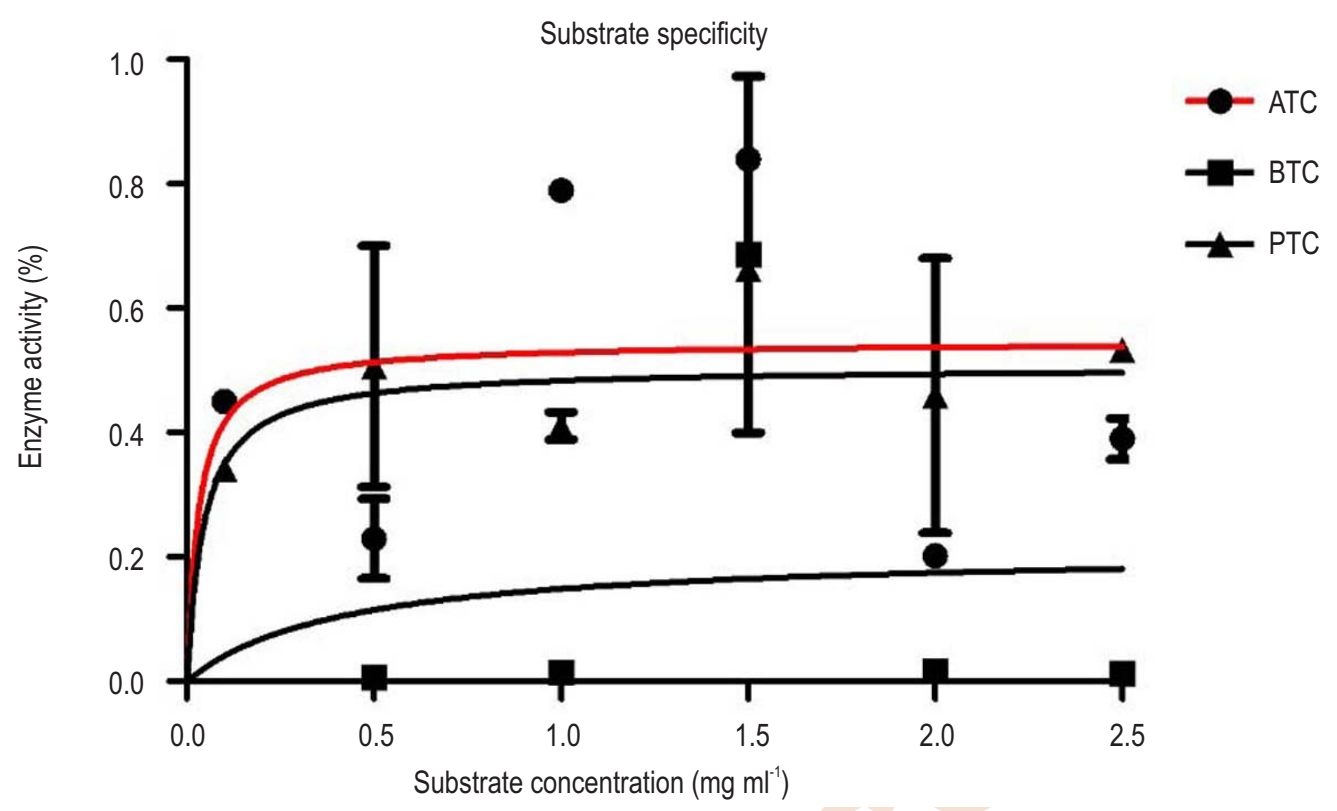

Fig. 3 : Substrate specificity profile of three synthetic substrates, namely, acetylthiocholine iodide (ATC), butyrylthiocholine iodide (BTC) and propionylthilcholine iodide (PTC) at different concentration ranging from 0 to $2.5 \mathrm{mM}$ incubated with partially purified ChE from gill extract of $C$. gariepinus. All values are mean of three replicates \pm S.E.

process were acetate, phosphate and Tris- $\mathrm{HCl}$ buffers at different $\mathrm{pH}$ range. Fig. $4 \mathrm{~A}$ shows comparison between three types of buffer showing the most optimum parameter for highest AChE activity at $\mathrm{pH} 10$ using $0.1 \mathrm{M}$ Tris- $\mathrm{HCl}$. Similar results were recorded by Sabullah et al. (2014), who demonstrated that $\mathrm{pH} 8$ of Tris-HCl was most optimum for $\mathrm{ChE}$ activities in different types of fish used for the study. The assay for the most optimum buffer and $\mathrm{pH}$ is important for the later stage of the study as unfavourable condition can negatively impact the enzyme. Masson et al. (2002) reported that $\mathrm{pH}$ change can cause protonation of imidazole group of histidine that exist at catalytic triad, thus affecting the formation of enzyme-substrate complex.

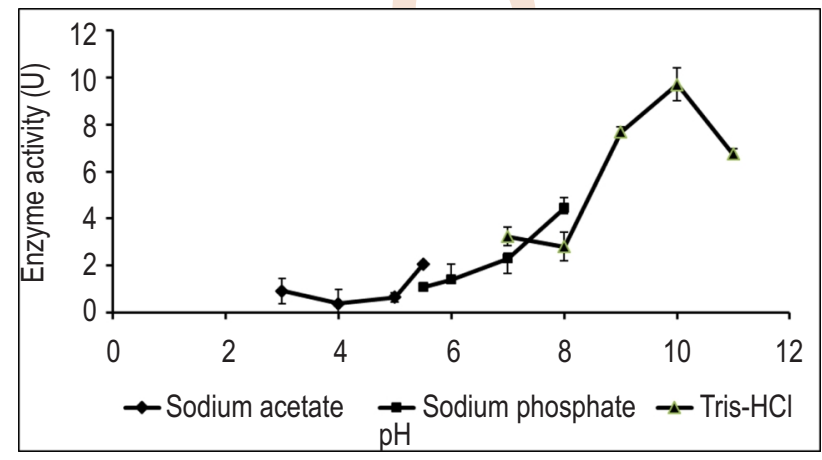

The optimum temperature for AChE activity in gills was $35^{\circ} \mathrm{C}$ using $\mathrm{pH} 10$ Tris- $\mathrm{HCl}$ buffer (Fig. 4B). When temperature was low, the enzyme activity was found to be lowest. However, with increase in temperature upto $35^{\circ} \mathrm{C}$, the enzyme activity increased producing a bell shaped curve. The stability of protein was lost due to denaturation process, which explained decrease in enzyme activity above $35^{\circ} \mathrm{C}$. Hayat et al. (2015), reported the maximum $\mathrm{ChE}$ activity in gills of $L$. calcarifer at temperature ranging of between 20 to $30^{\circ} \mathrm{C}$. This result is also in accordance with the previous study of Sabullah et al. (2014), who reported that the optimum temperature for ChE extracted from Puntius javanicus ranged between $25^{\circ} \mathrm{C}$ to $35^{\circ} \mathrm{C}$. In an

Fig. 4 : Optimisation of (A) pH and (B) temperature for ChE from C. gariepinus. Error bars represent mean of three replicates \pm S.E. 
another study Ahmad et al. (2016a) observed maximum activity of $\mathrm{ChE}$ in Anabas testudineus muscles in the range of $25^{\circ} \mathrm{C}$ to $40^{\circ} \mathrm{C}$, while the maximum activity of blood $\mathrm{ChE}$ was observed at $30^{\circ} \mathrm{C}$. It can be concluded that this particular enzyme works best at temperature ranging from $20^{\circ} \mathrm{C}$ to $40^{\circ} \mathrm{C}$ that prevails in Malaysia, a tropical country with warm temperature, high humidity and copious rainfall and average temperature of around $27^{\circ} \mathrm{C}$ (Hii et al., 2016). The results this study indicate that cadmium induces toxicity on $C$. gariepinus, and AChE present in the gills of $C$. gariepinus may serve as a significant biomarker of cadmium induced neurotoxicity.

\section{Acknowledgments}

This project was supported by a fund (Putra-IPS) received from Universiti Putra Malaysia under the Grant Numbers 9481400,9571700 and 9600600 . We also thank Universiti Putra Malaysia for providing GRF scholarship to Miss Nadia Izzati Fadzil, Ain Aqilah Basirun and Nurul AidaAsri.

\section{References}

Adham, K.G., A.A. Nadia and H.F. Manal: Risk assessment of heavy metal contamination in soil and wild Libyan jird Meriones libycus in Riyadh, Saudi Arabia. J. Environ. Biol., 32, 813-819 (2011).

Agtas, S., H. Gey and S. Gul: Concentration of heavy metals in water and chub, Leuciscus cephalus (Linn.) from the river Yildiz, Turkey. J. Environ. Biol., 28, 845-849 (2007).

Ahmad, S.A., M.K. Sabullah, A.A. Basirun, A. Khalid, N.A. Yasid, I.M Iqbal, N.A. Shamaan, M.A. Syed and M.Y. Shukor: Evaluation of cholinesterase from the muscle and blood of Anabas testudineus as detection of metal ions. Fresen. Environ. Bul., 25, 4253-4260 (2016a).

Ahmad, S.A., M.K. Sabullah, N.A. Shamaan, M.Y. Shukor, H. Jirangon, A. Khalid and M.A. Syed: Evaluation of acetylcholinesterase source from fish, Tor tambroides for detection of carbamate. J. Environ. Biol., 37, 479-484 (2016b).

Ahmad, S.A., Y.F. Wong, M.Y. Shukor, M.K. Sabullah, N.A. Yasid, N. Hayat, N.A. Shamaan, A. Khalid and M.A. Syed: An alternative bioassay using Anabas testudineus (Climbing perch) cholinesterase for metal ions detection. J. Int. Food Res., 23, 1446-1452 (2016c).

Alina, M., A. Azrina, M.Y. Shukor, S.M. Zakiuddin, M.I.H. Effendi and R. Muhammad Rizal: Heavy metals (mercury, arsenic, cadmium, and plumbum) in selected marine fish and shellfish along the Straits of Malacca. J. Int. Food Res., 19, 135-140 (2012).

Athikesavan, S., S. Vincent, T. Ambrose and B. Velmurugan: Nickel induced histopathological changes in the different tissues of freshwater fish, Hypophthalmichthys molitrix (Valenciennes). J. Environ. Biol., 2, 391-395 (2006).

$\mathrm{Au}$, D.W.T.: The application of histo-cytopathological biomarkers in marine pollution monitoring: A review. Mar. Pollut. Bull., 48, $817-$ $834(2004)$

Boyd, R.S.: Heavy metal pollutants and chemical ecology: Exploring new frontiers. J. Chem. Ecol., 36, 46-58 (2010).

Bradford M.M.: A rapid and sensitive method for the quantitation of microgram quantities of protein utilizing the principle of protein dye binding. Anal. Biochem., 72, 248-254, (1976).

Butchiram, M.S., M. Vijaya Kumar and K.S. Tilak: Studies on the histopathological changes in selected tissues of fish Labeo rohita exposed to phenol. J. Enviro. Biol., 34, 247-251 (2013).

Chavan, V.R. and D.V. Muley: Effect of heavy metals on liver and gill of fish Cirrhinus mrigala. Int. J. Curr. Microbiol. App. Sci., 3, 277-288 (2014).

Eisler, R.: Biological Report. 1.10. Vol. 85. US Fish and Wildlife Service; Washington DC: 1987. Mercury hazards to fish, wildlife and invertebrates: Asynoptic review.

Ellman, G.L., K.D. Courtney, V. Andres and R.M. Featherstone: A new and rapid colorimetric determination of acetylcholinesterase activity. Biochem. Pharmacol., 7, 88-95(1961).

Förstner, U. and F. Prosi: Heavy metal pollution in freshwater ecosystems. Biological aspects of freshwater pollution: Proceedings of the Course Held at the Joint Research Centre of the Commission of the European Communities, Ispra, Italy (2013).

Hayat, N.M., S.A. Ahmad, N.A. Shamaan, M.K. Sabullah, M.Y. Abd Shukor, M.A. Syed, A. Khalid, K.A. Khalil and F.A. Dahalan: Characterisation of cholinesterase from kidney tissue of Asian Sea bass (Lates calcarifer) and its inhibition in presence of metal ions. J. Environ. Biol., 38, 383-388 (2017)

Hayat, N.M., N.A. Shamaan, M.Y. Shukor, M.K. Sabullah, M.A. Syed, A. Khalid, F.A. Dahalan and S.A. Ahmad: The use of Lates calcarifer as a biomarker for heavy metals detection. Rend. Fis. Acc. Lincei., 27, 463-472 (2016).

Hayat, N.M., N.A. Shamaan, M.Y. Shukor, M.K. Sabullah, M.A. Syed, A. Khalid and S.A. Ahmad: Cholinesterase-based biosensor using Lates calcarifer (Asian Seabass) brain for detection of heavy metals. J. Chem. Pharm. Sci., 8, 376-381 (2015).

Hee, H.N. and M. Kottelat: The identity of Clarias batrachus (Linnaeus, 1758), with the designation of a neotype (Teleostei: Clariidae). Zool. J. Linn. Soc., 153, 725-732 (2008).

Hii, Y.L., R.A. Zaki, N. Aghamohammadi and J. Rocklöv: Research on climate and dengue in Malaysia: A systematic review. Curr. Environ. Hlth. Rep., 3, 81-90 (2016).

Jebali, J., S. Ben Khedher, M. Sabbagh, N. Kamel, M. Banni and H. Boussetta: Cholinesterase activity as biomarker of neurotoxicity: Utility in the assessment of aquatic environment contamination. J. Integr. Coast Zone Manage., 13, 525-537 (2013).

Kumar, M., P. Kumar and S. Devi: To study the histopathological changes in the gills of Clarias batrachus, an air breathing teleost after short term exposure of copper sulphate. J. Aquac. Res. Develop., 6, 369 (2015).

Li, H., L. Tong, L.M. Schopfer, P. Masson and O. Lockridge: Fast affinity purification coupled with mass spectrometry for identifying organophosphate labeled plasma butyrylcholinesterase. Chem. Biol. Interact., 175, 68-72 (2008).

Mabika, N., B. Utete, T. Nhiwatiwa and M. Barson: Metal correlations and mobility in sediment and water from the Gwebi river in the Upper Manyame Catchment, Zimbabwe. Int. J. Water Sc., 2, 1-8 (2013).

Mahboob, S., S. Sultana, T. Sultana, L. Ahmad and M.R. Asi: Cholinesterases: Cholinergic biomarkers for the detection of sublethal effects of organophosphorous and carbamates in Catla catla. Int. J. Agric. Biol., 16, 1560-8530 (2014).

Masson, P., L.M. Schopfer, C.F. Bartels, M.T. Froment, F. Ribes, F. Nachon and O. Lockridge: Substrate activation in acetylcholinesterase induced by low $\mathrm{pH}$ or mutation in the $\pi$-cation subsite. Biochimica et BiophysicaActa, 1594, 313-324 (2002).

Mehrani, $\mathrm{H}$.: Simplified procedures for purification and stabilization of human plasma butyrylcholinesterase. Process Biochem., 39, 877882 (2004).

Monteiro, M., C. Quintaneiro, F. Morgado, A.M.V.M. Soares and L. Guilhermino: Characterization of the cholinesterases present in head tissues of the estuarine fish Pomatoschistus microps: Application to biomonitoring. Ecotoxicol. Environ. Saf., 62, 341347 (2005).

Miller, J.N. and J.C. Miller: Statistics and Chemometrics for Analytical 
Chemistry. $4^{\text {th }}$ Edn., Harlow, England, New York, Prentice Hall, p. 271 (2000).

Nigam, A.K., N. Srivastava, A.K. Rai, U. Kumari, A.K. Mittal and S. Mittal: The first evidence of cholinesterases in skin mucus of carps and its applicability as biomarker of organophosphate exposure. Environ. Toxicol., 29, 788-796 (2014).

Padrilah, S.N., S.A. Ahmad, N.A. Yasid, M.K. Sabullah, H.M. Daud, A Khalid and M.Y. Shukor: Toxic effects of copper on liver and cholinesterase of Clarias gariepinus. Environ. Sci. Pollut. Res. Int., 24, 22510-22523 (2017).

Playle, R.C., R.W. Gensemer and D.G. Dixon: Copper accumulation on gills of fathead minnows: Influence of water hardness, complexation and $\mathrm{pH}$ of the gill micro environment. Environ. Toxicol. Chem., 11, 381-391 (1992).

Sabullah, M.K., M.R. Sulaiman, M.Y. Abd Shukor, N.A. Shamaan, A. Khalid and S.A. Ahmad: In vitro and in vivo effects of Puntius javanicus cholinesterase by copper. Fresen. Environ. Bull., 24, 4615-4621 (2015a)

Sabullah, M.K., M.R. Sulaiman, M.Y.A. Shukor, M.A. Syed, N.A. Shamaan, A. Khalid and S.A. Ahmad: The assessment of cholinesterase from the liver of Puntius javanicus as detection of metal ions. The Sci. World J., 2014 (2014). doi :http://dx.doi.org/ 10.1155/2014/571094.

Sabullah, M.K., S.A. Ahmad, M.Y. Shukor, A.J. Gansau, M.A. Syed, M.R Sulaiman and N.A. Shamaan: Heavy metal biomarker: Fish behavior, cellular alteration, enzymatic reaction and proteomics approaches. J. Int. Food Res., 22, 435-454 (2015b).

Sulaiman, M.R. and C.H.S. Mei: Update of mercury in fish with a focus on its currentstatus in Malaysia. J. Environ. Bioreme. Toxicol., 1, 14$19(2013)$.

Tham, L.G., N. Perumal, M.A. Syed, N.A. Shamaan, and M.Y. Shukor: Assessment of Clarias batrachus as a source of acetylcholinesterase (AChE) for the detection of insecticides. J. Environ. Biol., 30, 135-138 (2009).

Todd, P.A., X. Ong and L.M. Chou: Impacts of pollution on marine life in SouthEast Asia. Biodivers. Conserv., 19, 1063-1082 (2010).

Zeitoun, M.M. and E.S.E. Mehana: Impact of water pollution with heavy metals on fish health: Overview and updates. Global. Vet., 12, 219231 (2014). 